University of Montana

ScholarWorks at University of Montana

$12-2001$

\title{
Facilitation and Competition on Gradients in Alpine Plant Communities
}

Philippe Choler

Richard Michalet

Ragan M. Callaway

University of Montana - Missoula, Ray.Callaway@mso.umt.edu

Follow this and additional works at: https://scholarworks.umt.edu/biosci_pubs

Part of the Biology Commons

Let us know how access to this document benefits you.

\section{Recommended Citation}

Choler, Philippe; Michalet, Richard; and Callaway, Ragan M., "Facilitation and Competition on Gradients in Alpine Plant Communities" (2001). Biological Sciences Faculty Publications. 230.

https://scholarworks.umt.edu/biosci_pubs/230

This Article is brought to you for free and open access by the Biological Sciences at ScholarWorks at University of Montana. It has been accepted for inclusion in Biological Sciences Faculty Publications by an authorized administrator of ScholarWorks at University of Montana. For more information, please contact

scholarworks@mso.umt.edu. 


\title{
FACILITATION AND COMPETITION ON GRADIENTS IN ALPINE PLANT COMMUNITIES
}

\author{
Philippe Choler, ${ }^{1,4}$ Richard Michalet, ${ }^{2}$ and Ragan M. Callaway ${ }^{3}$ \\ ${ }^{1}$ Station Alpine du Lautaret \& Laboratoire de Biologie des Populations d'Altitude, UMR CNRS-UJF 5553, \\ University Joseph Fourier, Grenoble, BP 53, 38041 Grenoble cedex, France \\ ${ }^{2}$ Laboratoire Ecosystèmes et Changements Environnementaux, University Joseph Fourier, Grenoble, BP 53, \\ 38041 Grenoble cedex, France \\ ${ }^{3}$ Division of Biological Sciences, University of Montana, Missoula, Montana 59812 USA
}

\begin{abstract}
We conducted a neighbor removal experiment in natural alpine plant communities of the southwestern Alps to test for the relative importance of competitive and facilitative interactions along elevational and topographical gradients. The experimental sites were chosen to encompass most of the floristic diversity observed along gradients of elevation and topography, which are the two main ecological gradients associated with alpine plant communities in the western Alps. The effects of neighbor removal on the survival, aboveground biomass, and reproduction of five target species were tested at each of six experimental sites. Using biomass data, we calculated relative competitive index (RCI) and log response ratio (LRR) as measures of interaction strength and direction. We found highly significant shifts from strong competitive effects in low and sheltered sites to strong facilitative responses in high and exposed sites. When experimental results were integrated with gradient analyses, we found that the responses of particular alpine plant species to neighbor removal generally depended on the species' position on elevational and topographical gradients. When neighbors were removed from around target species at experimental sites that were lower in elevation than the distributional mean of the target species, biomass generally increased. When neighbors were removed from around target species at experimental sites that were higher in elevation than the distributional mean of the target species, biomass decreased. In other words, facilitation appeared to allow species from lower elevations to move up the gradient, but competition at low elevations appeared to restrict species from higher elevations from moving down the gradient. In high and exposed sites, experimental evidence for facilitation was coupled to small-scale spatial associations among species, but spatial disassociation was not coupled to experimental evidence for competition at any sites. We conclude that the distribution and abundance of many species in high-elevation communities of the western Alps appears to be enhanced by neighbors, and that species continua commonly observed along environmental gradients are the result of both negative and positive plant interactions.
\end{abstract}

Key words: alpine tundra; competition; elevation gradient; facilitation; log response ratio (LRR); niche theory; ordination; plant communities; plant interactions; relative competitive index (RCI); removal experiment; topography gradient.

\section{INTRODUCTION}

Many recent studies have shown that plant species can have strong, and often species-specific, direct and indirect positive effects on other plant species (Hunter and Aarssen 1988, Wilson and Agnew 1992, Bertness and Callaway 1994, Callaway 1995, 1997, 1998a). The common occurrence of positive interactions, or facilitation, suggests that plant species may not always be distributed independently of each other. Bertness and Callaway (1994) proposed a conceptual model in which the relative importance of positive interactions to the organization of plant communities increased with abiotic stress, and the relative importance of competition decreased (see also Brooker and Callaghan [1998]).

Manuscript received 31 January 2000; revised 11 January 2001; accepted 16 January 2001.

${ }^{4}$ E-mail: philippe.choler@ujf-grenoble.fr
Some experimental studies support this model in general (Walker and Chapin 1987, Bertness and Shumway 1993, Bertness and Hacker 1994, Greenlee and Callaway 1996, Callaway 1998b, Kitzberger et al. 2000), whereas others do not (Moen 1993, Olofsson et al. 1999). However, if the relative importance of facilitation and competition varies along environmental gradients, species may be somewhat interdependent at some points along environmental gradients, but not at others. Few studies have examined interactions among large numbers of species along environmental gradients, and to our knowledge there have been few efforts to integrate experimental results with gradient analyses. Del Moral (1983) and Wilson and Keddy (1986) examined interactions among a large number of species differing by their positions along environmental gradients in subalpine and wetland communities, respectively, but to our knowledge there have been no studies 
TABLE 1. Features of the six experimental sites.

\begin{tabular}{|c|c|c|c|c|c|c|c|c|c|}
\hline Site $\dagger$ & $\begin{array}{l}\text { Elevation } \\
\text { (m) }\end{array}$ & $\begin{array}{l}\text { Dominant } \\
\text { graminoids }\end{array}$ & Aspect & $\begin{array}{c}\text { Slope } \\
\left({ }^{\circ}\right)\end{array}$ & $\begin{array}{l}\text { Vegeta- } \\
\text { tion } \\
\text { cover } \\
(\%)\end{array}$ & $\begin{array}{c}\text { No. } \\
\text { species/ } \\
50 \mathrm{~m}^{2}\end{array}$ & Bedrock & $\begin{array}{l}\text { No. } \\
\text { snowfree } \\
\text { days }\end{array}$ & $\begin{array}{l}\text { Aboveground } \\
\text { phytomass } \\
\left(\mathrm{g} / \mathrm{m}^{2}\right) \ddagger\end{array}$ \\
\hline L-S & 2100 & Nardus stricta & flat & 0 & 100 & 25 & Colluvium & $100-150$ & $424 \pm 97$ \\
\hline L-E & 2100 & Carex sempervirens & flat & 0 & 95 & 32 & Dolomite & $200-250$ & $315 \pm 30$ \\
\hline I-S & 2550 & Festuca violacea & E & 10 & 100 & 22 & Colluvium & $100-150$ & $305 \pm 45$ \\
\hline I-E & 2550 & Sesleria coerulea & SE & 30 & 70 & 24 & Shales & $200-250$ & $149 \pm 35$ \\
\hline $\mathrm{H}-\mathrm{S}$ & 2900 & Alopecurus alpinus & flat & 0 & 100 & 18 & Colluvium & $<80$ & $67 \pm 29$ \\
\hline H-E & 2900 & Festuca quadriflora & SW & 30 & 40 & 16 & Shales & $>250$ & $89 \pm 18$ \\
\hline
\end{tabular}

$\dagger$ Abbreviations: L, I, and H for low-, intermediate-, and high-elevation sites; S for sheltered site; E for exposed site. \$ Aboveground green phytomass at the end of the growing season in 1998: mean \pm 1 SE of three measurements.

that have explicitly linked experiments with gradient analyses of community composition and structure.

Subalpine meadow and alpine tundra communities are well suited for experimental manipulation, gradient analyses, and spatial analyses. Species diversity is high, and there is high turnover in species composition with relatively small changes in landscape (Billings 1974). Correlations among plant distributions and environmental variables have been studied in a large number of alpine environments (Braun-Blanquet 1926, Komarkova and Webber 1978, Eddleman and Ward 1984, Isard 1986, Gensac 1990, Kirkpatrick and Bridle 1998). Furthermore, there are numerous studies of spatial associations among alpine and arctic plants in which extreme clumping among species has been interpreted as evidence for facilitation (Sohlberg and Bliss 1984, Alliende and Hoffman 1985, Kikvidze 1993, Aksenova et al. 1998, Kikvidze and Nakhutsrishvili 1998, Nuñez et al. 1999).

We explored the relative roles of competition and facilitation as determinants of alpine plant community organization by integrating experimental analyses of interactions along elevational and topographical gradients with large-scale descriptions of species distributions along those same gradients, and by comparing experimental results to small-scale spatial associations among species. We focused on the following questions: (1) Does the importance of competition decrease and the importance of facilitation increase in plant communities with increasing environmental stress? (2) Is facilitation more important at the upper end of species distributions? (3) Is the distribution of a species correlated with its response to its neighbors? (4) Are spatial relationships among species correlated with interaction directions and strengths?

\section{Methods \\ Field sites}

All fieldwork was conducted in the southwestern part of the French Alps (Table 1). Low elevation experimental sites were located at L'Alpe d'Huez (2100 m), $\sim 50 \mathrm{~km}$ east of Grenoble, France. Intermediate experimental sites $\left(2600 \mathrm{~m}, 45^{\circ} 02^{\prime} \mathrm{N}, 6^{\circ} 24^{\prime} \mathrm{E}\right)$ were located at the Col du Lautaret near the Alpine Field Station of
Lautaret, $\sim 100 \mathrm{~km}$ east of Grenoble. Our highest site was at Col Agnel $(2900 \mathrm{~m})$ on the France-Italy border, $\sim 150 \mathrm{~km}$ east of Grenoble. At the Col du Lautaret, mean temperature of the warmest month (July) is $11^{\circ} \mathrm{C}$, and average yearly precipitation is $1230 \mathrm{~mm}$. Climatic data for the two other sites were unavailable. Natural tree line, $\sim 2300 \mathrm{~m}$, at our experimental sites would be higher than the current tree line, which has been lowered due to long-term effects of grazing and logging, and is now formed by Pinus cembro.

\section{Gradient analyses and community description}

We had two primary goals for conducting gradient analyses. The first was to quantify the positions of species along elevational and topographical gradients, thereby providing a large-scale spatial and community context for our experiments. The second goal was to quantify the relative abundance of species used in experiments, so that the relationship between abundance and the effects of neighbors could be quantified.

Our data set for gradient and community analyses comprised 256 relevés of alpine tundra in the south western part of the Alps, an area approximately delineated by the cities Grenoble, Turin, and Barcelonnette to the west, east, and south, respectively. Each relevé was conducted using standard phytosociological rules in herbaceous stands with vegetation cover $>30 \%$ (Braun-Blanquet 1932). Relevés do not have fixed areas, and are conducted by visually estimating the relative abundance of vascular plant species within a contiguous, homogeneous area of $\sim 50 \mathrm{~m}^{2}$. Mires and bogs were not included. The locations of the relevés were chosen so that different mountain ranges, altitudes, topographic positions, and substrates were sampled in a roughly stratified approach.

For each relevé, we recorded elevation (meters above sea level), relative north aspect (sine of aspect, from +1 north to -1 south, with flat coded 0 ), slope inclination (in degrees), acidity of substrate (dominant bedrocks include hard calcareous rocks, shales, metamorphic rocks, and granites), and mesotopographical landform (an index quantifying a range from convexity to concavity at the decameter scale). All variables were 
treated as quantitative discrete variables in subsequent multivariate analysis.

All multivariate analyses were carried out using the ADE-4 software package (Thioulouse et al. 1997). Ordination of the vegetation was performed with both relative abundance and presence/absence data using correspondence analysis (CA). The results did not differ markedly, therefore we only present results from the latter data set. Rare species (frequency $<5 \%$ ) were removed before analyses. Correspondence analysis axes are derived only from the total floristic data set and are not produced by any direct environmental measurement. This unconstrained ordination corresponds to an indirect gradient analysis (ter Braak and Prentice 1988). Correspondence analysis axes representing latent variables were subsequently related to normalized environmental variables. Multiple regression between normalized relevés, CA scores (dependent variables), and environmental variables (explanatory variables) was performed with the module "LinearReg" of the ADE-4 software package.

Using the CA data set, the reciprocal scaling procedure was followed according to the method described by Thioulouse and Chessel (1992). This allows the location of both species and relevés on the same ordination plan, with each species or each relevé represented by an ellipse. The center of the ellipse is given by the mean of ordination scores, and axes of the ellipse are related to the variance of ordination scores. It is postulated that in such an analysis the mean score of a species is related to its distributional optimum along latent environmental variables, and that the variance is related to the species tolerance (or niche width) along these variables. For relevés, the variance is related to within-sample species diversity (Thioulouse and Chessel 1992). These calculations allowed us to examine competitive and facilitative responses as a function of species' distributions along large-scale environmental gradients.

\section{Spatial pattern}

Many studies use spatial associations or disassociations to infer facilitative or competitive interactions (see Callaway 1995). To examine small-scale spatial relationships among species, and to examine the correlations between spatial relationships and experimental results, we recorded the presence/absence of each vascular species in 300 randomly chosen $100-\mathrm{cm}^{2}$ square plots at each of the six experimental sites. For the analyses, rare species (frequency $<5 \%$ ) were removed. Two by two contingency tables were computed for each pair of species, and significant associations between species were tested with $G$ tests of independence (Sokal and Rohlf 1981). We conducted the same test with dominant graminoids of a site combined into one group (grasses or sedges with relative frequency $>40 \%$ ). Because graminoids are widely thought to be the dominant competitors in our alpine communities, this was performed to examine specific associations between each forb species and the graminoids.

\section{Experimental design}

We chose six experimental sites at the three different locations (two at each) as described (Table 1). At each elevation, an experimental site $\left(100-150 \mathrm{~m}^{2}\right)$ was located in a concave site (hereafter "sheltered"), which is more mesic because of the long duration of snow cover, and a convex site (hereafter "exposed"), which is more xeric because of the short duration of snow cover. We refer to these sites as differing at the "mesotopographic" scale after Billings (1974), because the variation occurred over tens of meters. These sites were well distributed throughout the range of relevés produced by the CA, indicating that they were broadly representative of the full range of alpine communities in the southwestern Alps (Fig. 1). Furthermore, this choice of experimental sites allowed us to explore interaction strengths and directions along the two main abiotic gradients associated with alpine plant communities in the western Alps (Gensac 1990, Bounemoura et al. 1998).

Interactions among plants were assessed by the removal of all aboveground biomass of neighboring species around a target individual, and comparison of target plant performance to that of controls in which neighbors were left intact. The area clipped was $\sim 15-$ $20 \mathrm{~cm}$ in diameter. This approach examines only the general effects of neighboring plants on a target, not the reciprocal effects or the effects of specific competitor species. Our removal treatments were probably conservative. Neighbors within $15-20 \mathrm{~cm}$ could have still given targets some shelter from wind, and, because the roots were left intact, neighbors could have still competed somewhat with targets for belowground ressources. At each site, five target species were chosen to represent a range of relative abundances. Four species were used at multiple sites. Several dominant species were not used as targets in the experiments because discrete individuals were too difficult to find for these species. We chose target individuals that were small relative to nearby conspecifics and for which distinct individuals or ramets could be found to minimize the effects of clonal connections on treatment effects. There were never other conspecific individuals within the $15-20 \mathrm{~cm}$ diameter experimental area around treatment and control individuals, and therefore targets were less likely to be highly clonally integrated. All 19 target species were clonal, but most of them (15 species) were cespitose and highly unlikely to be connected to plants beyond the space designated for our treatment area. Four target species were rhizomatous (Geum montanum, Lotus corniculatus, Polygonum viviparum, and Veronica allionii), and we could not be certain experimental ramets of these species were not connected belowground to other ramets. Therefore, we 


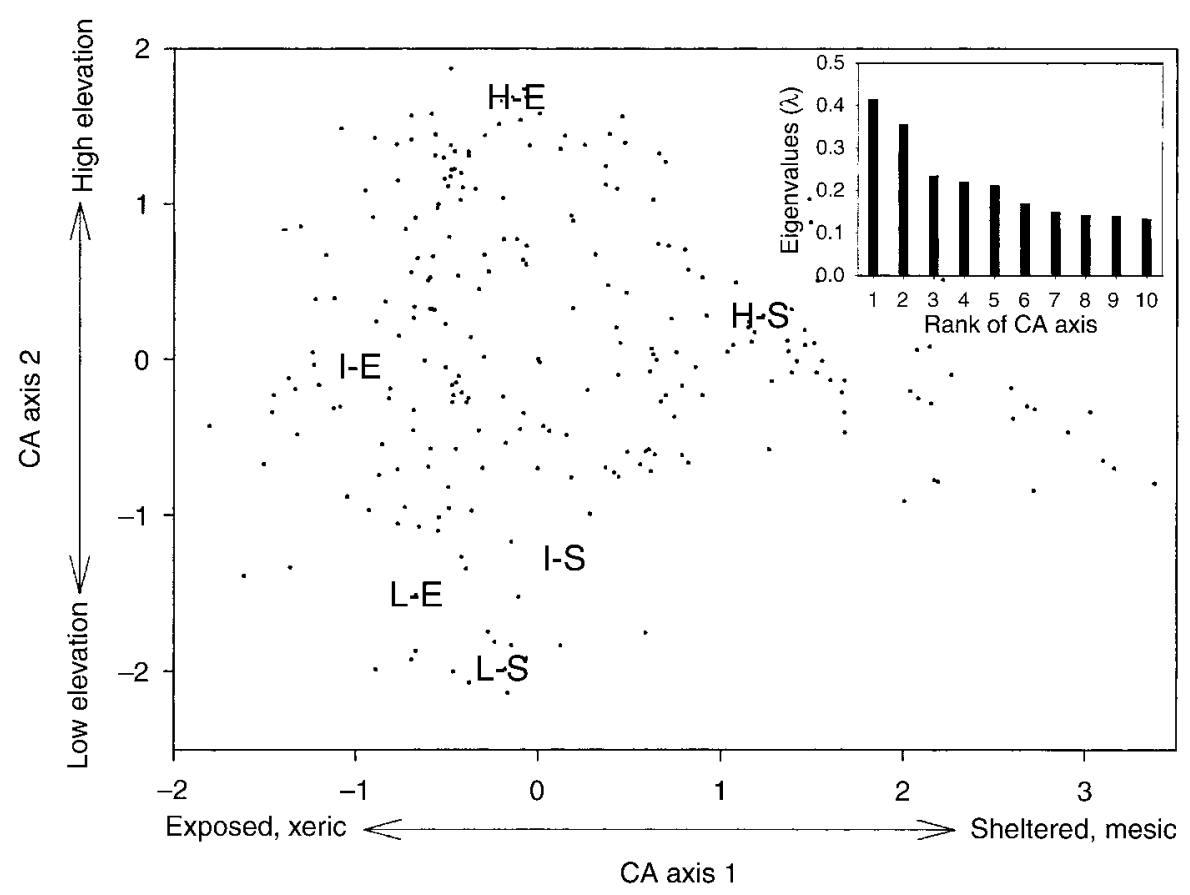

FIG. 1. Ordination of 256 alpine tundra vegetation relevés from the southwestern Alps using correspondence analysis (CA). Data from Ph. Choler (unpublished data), 20 relevés from Ph. Reynier (1988), and 10 relevés from C. Gandoy (unpublished data). Eigenvalues for the first 10 axes are shown in the inset. Locations of the experimental sites are indicated with the abbreviations as in Table 1 .

also conducted statistical analyses on a subset of data including only nonrhizomatous species.

For each species at each site, 12 pairs of individuals were chosen, and one of each was randomly selected for neighbor removal. Pairs were located as close as possible to each other and within the same apparent microenvironment. Care was taken to choose pairs of individuals that were as similar as possible (same shoot size, same number of leaves). Only individuals with no evidence of past flowering or fruiting were chosen in order to minimize the use of individuals that were in different phenological stages. We made no effort to choose species that showed a particular spatial relationship with other species or that occupied any particular position on elevational or topographic gradients. Hence, our choice of experimental plants may be described as haphazard, but not random.

We established the removal experiments at the beginning of July 1997, corresponding to two to three weeks after the beginning of the growing season. In 1998, vegetation growth was much more advanced, compared to 1997 , and plants were harvested at the end of July in the order in which the sites were established. Consequently, the experiment ran for almost two growing seasons. Aboveground regrowth around the targets was cut a second time in early June 1998, except for high sites where regrowth around targets was negligible. At the time we established the experiments, we counted the number of leaves for each target and control individual. At the harvest at the end of the second growing season, we recounted the number of leaves, counted flowers and fruits, documented the presence or absence of herbivory, recorded survival, harvested all aboveground parts of targets and controls, and measured mass after oven drying for $3 \mathrm{~d}$ at $70^{\circ} \mathrm{C}$. Although biomass is probably a more direct measure of plant success, we could not calculate growth rates using biomass because pretreatment biomass could not be measured without destroying the experiment.

\section{Statistical analysis}

All statistical analyses were carried out with Statistical Analysis System (SAS Institute 1985). We assumed that differences in aboveground biomass between removal treatments constitute a relevant indicator of strength and direction of biotic interaction as (1) vegetative parameters (leaf number, height or width of aerial parts) of both control and treated plants were similar at the beginning of the experiment, and (2) final aboveground biomass was shown to be tightly correlated to leaf number for all individuals.

For each pair of individuals, we calculated two competition intensity indices: $(1)-\ln \left(X_{\mathrm{r}} / X_{\mathrm{c}}\right)$ corresponding to the opposite of the log response ratio (LRR; Hedges et al. 1999), and (2) $-\left(X_{\mathrm{r}}-X_{\mathrm{c}}\right) / X_{\mathrm{r}}$ corresponding to the opposite of the relative competition intensity (RCI) (Markham and Chanway 1996: Eq. 1); where $X_{\mathrm{r}}$ and $X_{\mathrm{c}}$ are, respectively, the aboveground biomass of re- 
TABLE 2. Correlation coefficients between correspondence analysis (CA) scores on the first three axes and normalized environmental variables.

\begin{tabular}{lccc}
\hline \hline \multirow{2}{*}{\begin{tabular}{c} 
Environmental \\
\multicolumn{1}{c}{ variable }
\end{tabular}} & Axis 1 & Axis 2 & Axis 3 \\
\cline { 2 - 4 } & $0.20 *$ & $0.79 * * *$ & $0.04 \mathrm{NS}$ \\
Elevation & $-0.12 *$ & $-0.01 \mathrm{NS}$ & $-0.00 \mathrm{NS}$ \\
Slope inclination & $-0.14 *$ & $-0.18 \mathrm{NS}$ & $-0.28 * *$ \\
Aspect $\dagger$ & $0.10 \mathrm{NS}$ & $0.05 \mathrm{NS}$ & $-0.27 * *$ \\
Bedrock acidity $\ddagger$ & $0.57 * * *$ & $-0.27 * *$ & $-0.16 \mathrm{NS}$ \\
Mesotopography $\S$ & &
\end{tabular}

$* P<0.05$; ** $P<0.01 ; * * * P<0.001$; NS $=$ not significant at $P<0.05$ level.

$\dagger$ Sine of aspect, from +1 (north) to -1 (south), with flat coded 0 .

\$ Ranging from calcareous rocks to siliceous rocks.

$\S$ Index of mesotopographical form ranging from convexity to concavity.

moval and control individuals at time of harvest. We chose the opposite of LRR and RCI in order to get positive values for facilitative responses and negative values for competitive responses. When plants were found dead, corresponding pairs were excluded from the calculation. For each species, we compared the LRR or RCI sample mean with the expected mean of zero (i.e., no interaction or null hypothesis) using one sample $t$ test (Sokal and Rohlf 1981).

Using LRR or RCI as dependent variables, we performed two-way ANOVAs with elevation and topography as main effects, species nested within site and pairs as replicates. Survival of targets and occurrence of reproductive parts (flowers or fruits) at time of harvest were analyzed by a log-linear analysis (procedure CATMOD).

\section{RESUlts}

\section{Gradient analyses}

Correspondence analysis (CA) ordination of the vegetation relevés (axes 1 and 2) is depicted in Fig. 1. The histogram of eigenvalues showed that the first two axes (with $\lambda=0.41$ and 0.35 , respectively) were relevant. The variance accounted by the first and second axes was low (6.5\% and $5.5 \%$, respectively), as is usually found in such ordinations of large floristic data sets (Thioulouse et al. 1997). Results of the multiple regression clearly indicated that most of this variance was explained by the set of environmental variables (Table 2). The first CA axis showed a floristic gradient from snow bed communities to fell-field communities and was mainly related to the mesotopography (Table 2 ), which controls snowpack accumulation and therefore growing season length and soil water availability. The second CA axis was a strong elevation gradient (Table 2), ranging from subalpine grasslands and heathlands to subnival communities.

Experimental sites were chosen in order to encompass most of the floristic variation along both the first and second axes of the ordination, hence incorporate as much beta diversity as possible in the alpine tundra of the western Alps (see Fig. 1). Aboveground biomass decreased with increasing elevation (Table 1). Vegetation cover was particularly low in exposed, convex sites that were characterized by high levels of physical stress and disturbance (Table 1). The low elevationexposed site contained many plant species with subalpine affinities.

\section{Spatial patterns}

When spatial associations among pairs of species were assessed using $G$ tests for each species, no significant patterns were found, regardless of the site considered (data not shown). Dominant graminoids played a primary role in structuring high altitude vegetation, and field observations suggested that some forbs might be preferentially associated with graminoid tussocks regardless of the graminoid species. Therefore, we examined spatial associations at each site between the dominant graminoids pooled into a single category and each individual subordinate forb species. In this case, the number of significant spatial patterns between subordinates and graminoids increased with elevation and was higher in exposed sites relative to sheltered sites (Table 3). Moreover, significant positive associations were found only at the intermediate- and high-elevation sites.

\section{Field experiment}

Over all species at all sites, there was a strong shift from a negative effect of neighbors (competition) at low elevations and sheltered, concave microsites to positive effects of neighbors (facilitation) at high elevations and exposed, convex microsites. The same trend was observed for both relative competitive index (RCI; data not shown) and log response ratio (LRR; Fig. 2). At the low-sheltered site, all five species exhibited significant negative values of LRR, indicating strong competition. At the nearby exposed site at low elevation, two species were significantly suppressed by neighbors, and one species was significantly facilitated. There were no significant effects of neighbors at the

TABLE 3. Significant associations between individual subordinate species and all dominant graminoid species combined at each experimental site (from $G$ tests of independence).

\begin{tabular}{lccc}
\hline \hline Site & $\begin{array}{c}\text { No. species } \\
\text { examined }\end{array}$ & $\begin{array}{c}\text { No. positive } \\
\text { associations } \dagger\end{array}$ & $\begin{array}{c}\text { No. negative } \\
\text { associations } \dagger\end{array}$ \\
\hline L-S & 20 & 0 & 0 \\
L-E & 22 & 0 & 0 \\
I-S & 18 & 0 & 0 \\
I-E & 19 & 6 & 3 \\
H-S & 15 & 1 & 2 \\
H-E & 9 & 4 & 2 \\
\hline
\end{tabular}

Notes: Species with relative frequencies $<5 \%$ were disregarded. Abbreviations of sites are as in Table 1.

$\dagger$ Results from $G$ tests of independence with significant level at $P<0.05$. 

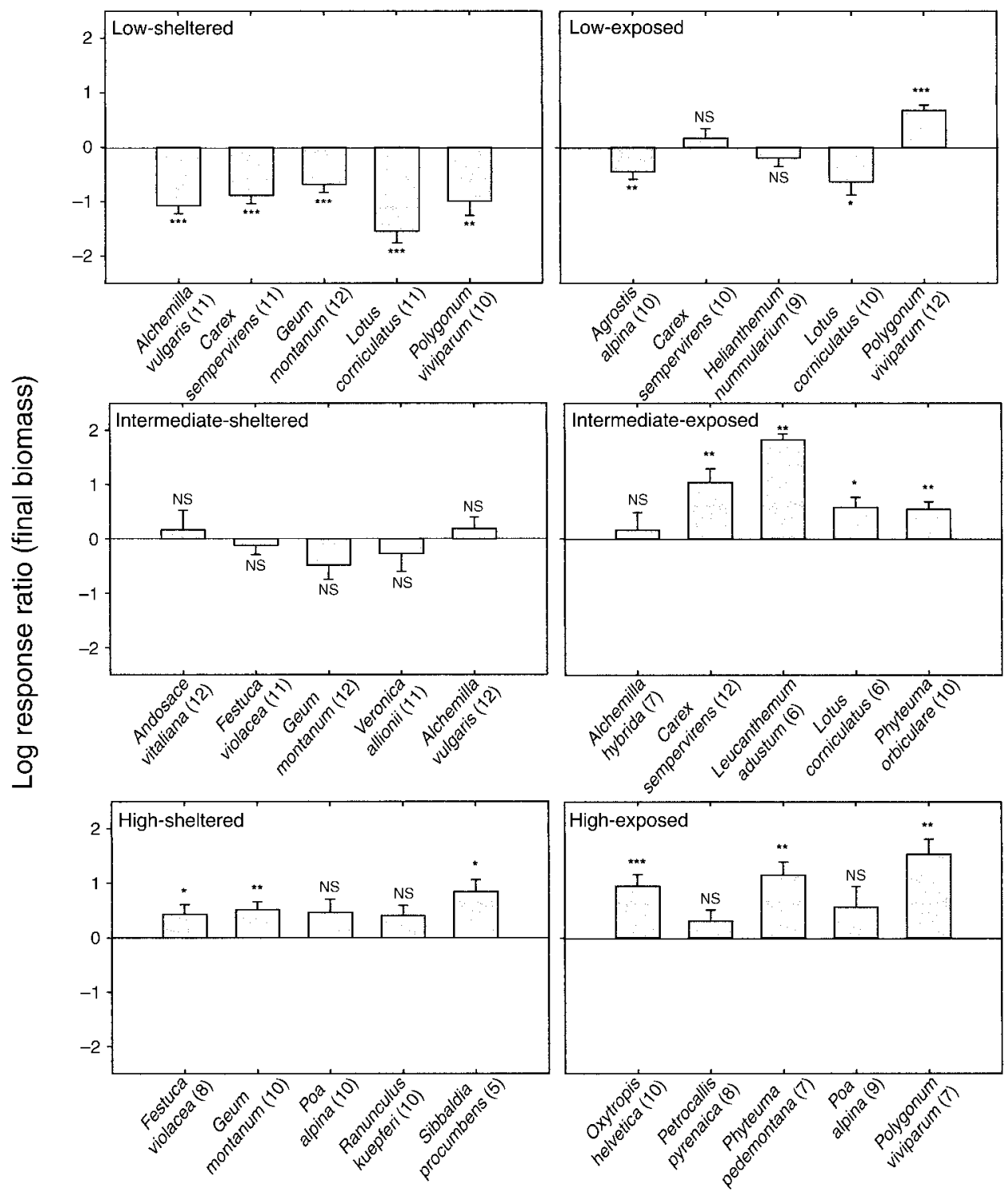

FIG. 2. Mean log response ratio (LRR) of each species in each site (sample sizes are given in parentheses). Positive values reflect facilitation; negative values reflect competition. Error bars represent 1 SE. $P$ values above bars indicate the probability of LRR $=0$ in a one-sample $t$ test: $* P<0.05$; ** $P<0.01$; ***P $P<0.001$; NS $=$ not significant at $P<0.05$ level.

intermediate-sheltered site, but there were four significant positive effects of neighbors at the intermediateexposed site. In contrast, there were strong overall (6 of 10 species) facilitative effects of neighbors at both high sites. Over all sites, the effects of elevation and topography on LRR indicated a significant shift from competition at low and sheltered sites to facilitation at high and exposed sites (elevation, $F_{2,29}=80.32, P<$ 0.001 ; topography, $\left.F_{1,29}=74.63, P<0.001\right)$. Further, the results were very similar (elevation, $F_{2,29}=41.62$, $P<0.001$; topography, $\left.F_{1,29}=30.79, P<0.001\right)$ when the ANOVA was conducted only with cespitose target species, suggesting that this general trend from com- petition to facilitation was not simply due to overrepresentation of rhizomatous species in our sampling.

Mortality was relatively low (a total of 45 plants out of 703), but increased significantly with elevation $\left(\chi^{2}\right.$ $=44.1, \mathrm{df}=2, P<0.001)$ and from sheltered to exposed sites $\left(\chi^{2}=11.9, \mathrm{df}=1, P<0.001\right)$. Removing neighbors significantly increased mortality $\left(\chi^{2}=22.7\right.$, df $=1, P<0.001)$, and this effect was stronger at higher elevation (treatment $\times$ elevation, $\chi^{2}=16.9$, df $=2, P<0.001$ ) and in exposed sites (treatment $\times$ topography, $\chi^{2}=17.0$, df $\left.=1, P<0.001\right)$.

Neighbor removal significantly enhanced flowering and fruiting of targets $\left(\chi^{2}=49.1\right.$, df $\left.=1, P<0.001\right)$, 
TABLE 4. Proportion of dead targets and proportion of flowering targets at the time of harvest.

\begin{tabular}{lccccc}
\hline \hline & \multicolumn{2}{c}{$\begin{array}{c}\text { Proportion of } \\
\text { dead targets }\end{array}$} & & \multicolumn{2}{c}{$\begin{array}{c}\text { Proportion of flowering } \\
\text { targets }\end{array}$} \\
\cline { 2 - 3 } \cline { 5 - 6 } Site $\dagger$ & Control & Removal & & Control & Removal \\
\hline L-S & $0 / 56$ & $0 / 59$ & & $0 / 56$ & $25 / 59$ \\
$\mathrm{~L}-\mathrm{E}$ & $0 / 59$ & $1 / 60$ & & $1 / 59$ & $13 / 60$ \\
$\mathrm{I}-\mathrm{S}$ & $0 / 59$ & $1 / 59$ & & $0 / 59$ & $12 / 59$ \\
$\mathrm{I}-\mathrm{E}$ & $4 / 57$ & $15 / 55$ & & $2 / 57$ & $8 / 55$ \\
$\mathrm{H}-\mathrm{S}$ & $4 / 59$ & $7 / 60$ & & $2 / 59$ & $7 / 59$ \\
$\mathrm{H}-\mathrm{E}$ & $0 / 60$ & $13 / 60$ & & $12 / 60$ & $11 / 60$ \\
Total & $8 / 350$ & $37 / 353$ & & $17 / 350$ & $76 / 353$ \\
\hline
\end{tabular}

Note: We were unable to find the position of a few targets at the end of the experiment. These missing plants account for the discrepancy with the 60 expected replicates of each cell.

$\dagger$ Abbreviations of sites are as in Table 1 .

except at the high-exposed site (Table 4). Treatment effect was more drastic on sheltered sites (treatment $\times$ topography, $\chi^{2}=8.8$, df $\left.=1, P<0.001\right)$.

\section{Relating field experiments to gradient analyses}

After the Correspondence Analysis, we used the reciprocal scaling technique to display species niche width and within-sample diversity on the same graph (Thioulouse and Chessel 1992). We calculated the differences between the ordination score of the relevé site at which the experiment was conducted and the ordination score of the target species. This resulted in negative numbers when a species was manipulated below its distributional mean and positive numbers when a species was manipulated above its distributional mean. The differences that were computed along the first and second CA axes were then plotted against LRR (Fig. 3 ). This allowed us to examine the effects of neighbors on particular species and at particular sites at different points along the natural distribution of species on abiotic gradients.

We observed a significant increase in LRR with increasing difference of ordination score along the second CA axis (Fig. 3). This suggests that significant responses to neighbor removal were related to the position of particular species along the elevational gradient that was strongly correlated to this second axis (see Table 2). When we conducted removal experiments on species at elevations above their distributional mean, the loss of neighbors was detrimental to the biomass of the target plant, indicating facilitation. Conversely, strong competitive responses were more common when target experimental species had a mean ordination score on axis 2 that was higher than the score of the site in which they were used for experimentation. In other words, when neighbors were removed from around a species occurring below its distributional mean, the loss of neighbors was beneficial to that plant, indicating competition.

We did not find similar relationships between the effects of neighbors and distribution mean-experimen- tal site differences along axis 1 (Fig. 3), which represented a gradient of sheltered-concave to exposedconvex topography.

Four species were used in experiments at three different sites. Therefore, we had the opportunity to study the effect of neighbor removal for the same species in different experimental sites; either above or below these species' distributional mean on the elevational gradient (axis 2). We found that the response of each species to neighbor removal depended on the site at which the experiment was conducted (Fig. 4). When the target species was manipulated near or below its elevational optimum (axis 2), the result was competition. When the target species was manipulated above its elevational optimum (axis 2), the result was facilitation. We only observed one case (out of 12) where a species responded in a facilitative manner well below
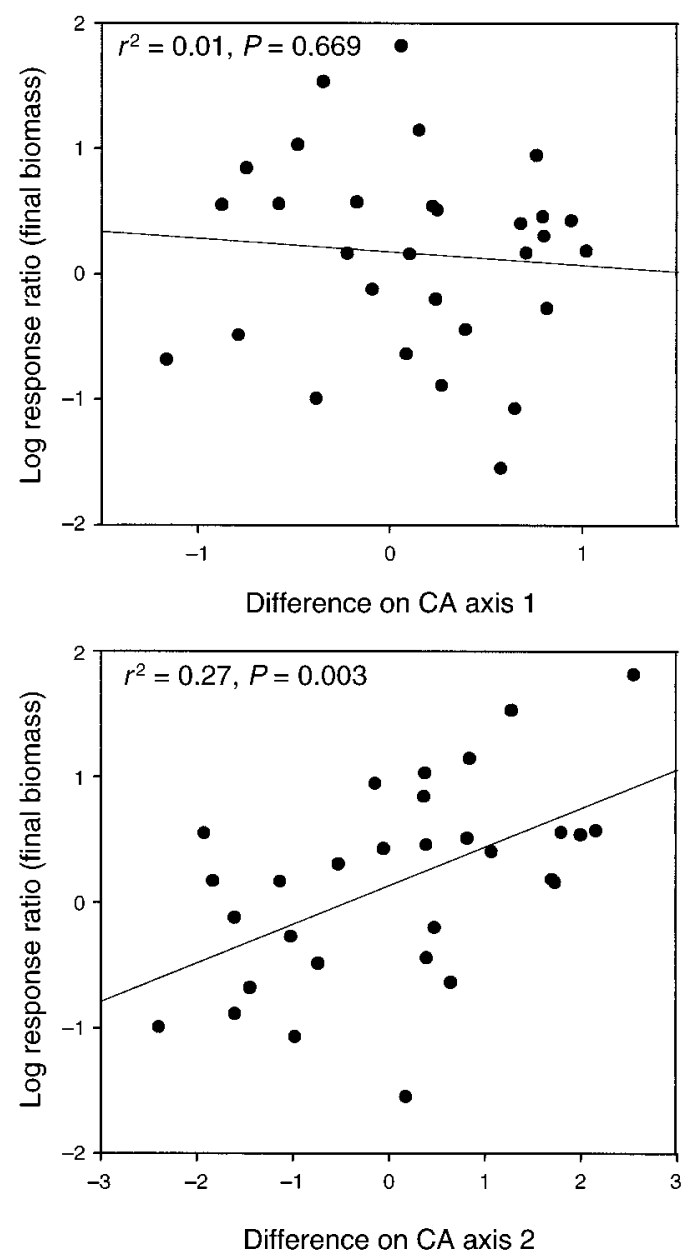

FIG. 3. Relationship between log response ratio (LRR) and difference between experimental site and species ordination scores along the first and second correspondence analysis (CA) axes. CA scores were rescaled according to Thioulouse and Chessel (1992). Calculation of these differences resulted in a negative number when a species was manipulated below its distributional mean and a positive number when a species was manipulated above its distributional mean. 

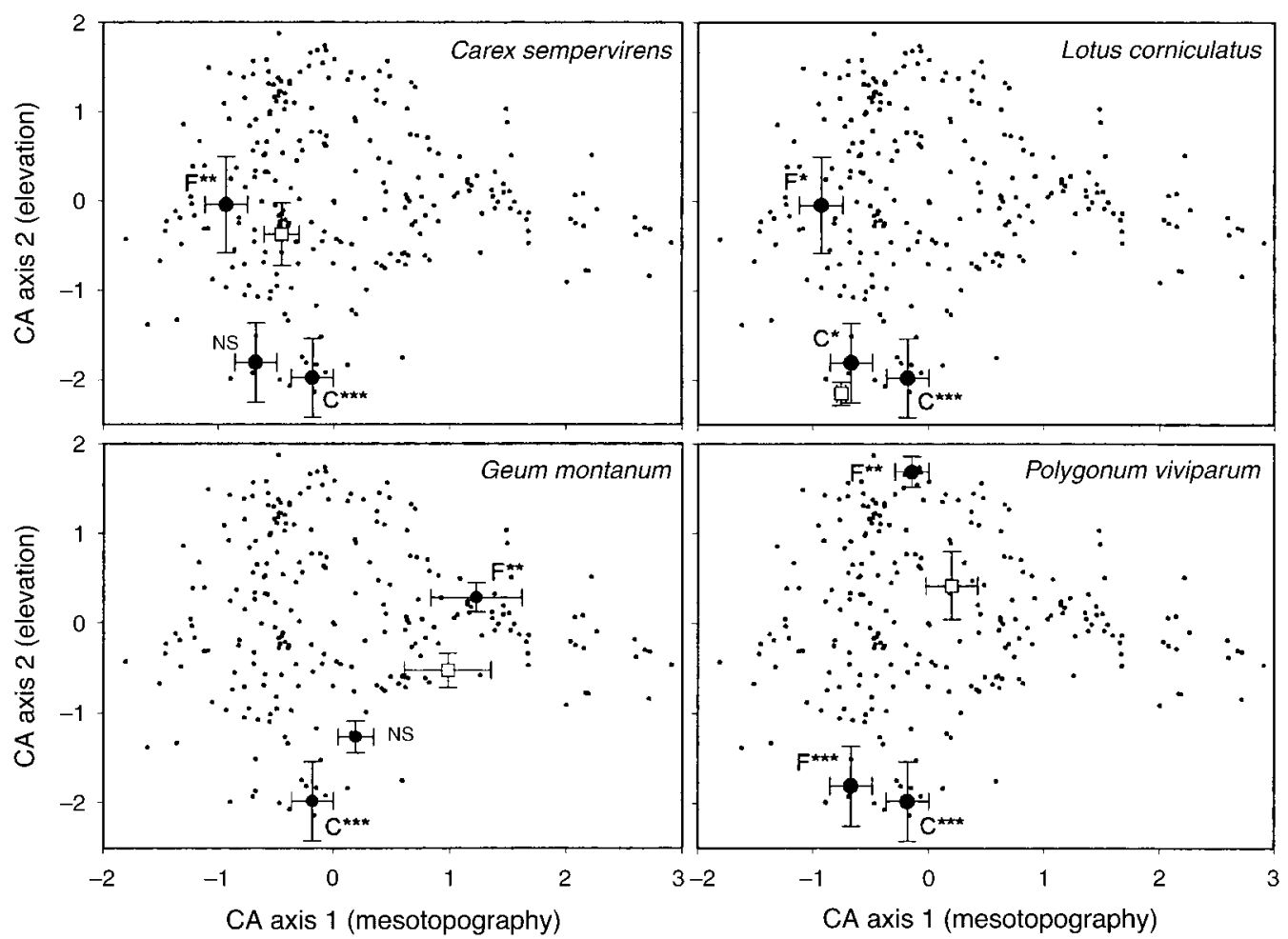

FIG. 4. Dual graphical display of species and relevé after reciprocal scaling of CA scores (Thioulouse and Chessel 1992). In each graph, the distributional mean $( \pm 1 \mathrm{SE}$ ) of one target species (open square) and the distribution mean ( $\pm 1 \mathrm{SE})$ of the experimental sites (solid circles) in which the species was manipulated are shown. Response to neighbor removal is indicated near the site in which the species was manipulated. $\mathrm{C}$ indicates competition, and $\mathrm{F}$ indicates facilitation: $* P<0.05 ; * * P<$ $0.01 ; * * * P<0.001 ; \mathrm{NS}=$ not significant at $P<0.05$ level.

its distributional optimum on the elevational gradient. There were no consistent differences in competitive and facilitative effects along axis 1 . These speciesspecific shifts from the competitive effect of neighbors to facilitative, or nonsignificant, effects of neighbors

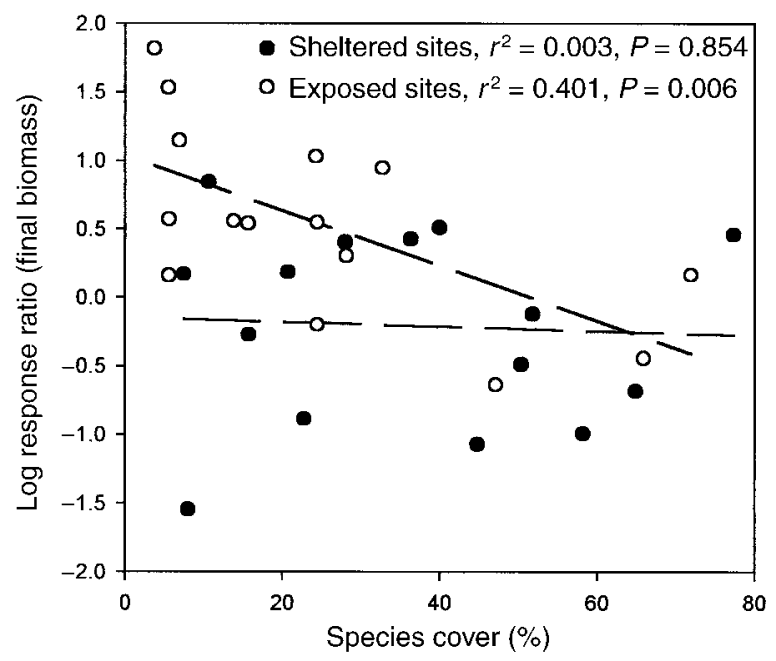

FIG. 5. Relationship between log response ratio (LRR) and relative species cover in exposed (open circles) or sheltered (solid circles) sites. along the elevational gradient corroborated the global pattern described in Fig. 3.

We tested relationships between the relative abundances of target species and the direction and strength of their responses to neighbor removal at the same site. We found that the effect of removing neighbors was more detrimental for uncommon than common species at experimental sites on exposed topography species (Fig. 5). The same trend was observed in each exposed site, i.e., in plant communities exhibiting large differences in total aboveground phytomass (see Table 1). There was no relationship between abundance and the strength of neighbor effects at the sheltered sites.

\section{Field experiments and spatial patterns}

Positive spatial associations between particular target species and graminoids in high-elevation and exposed microsites were often associated with facilitation (negative responses to neighbor removal) for those same species (Table 5). In contrast, competitive responses to neighbor removal in low-elevation sites were not significantly related to small-scale spatial patterns.

\section{Discussion}

We found that the general effects of neighbors changed from competition at low elevations and mesic, 
TABle 5. Comparisons of spatial associations with the experimental responses for target species.

\begin{tabular}{|c|c|c|}
\hline Target & Spatial $\dagger$ & Experiment $\$$ \\
\hline \multicolumn{3}{|l|}{$\mathrm{L}-\mathrm{S}$} \\
\hline Alchemilla vulgaris & NS & NS \\
\hline Geum montanum & NS & C*** \\
\hline Lotus corniculatus & NS & C*** \\
\hline \multirow{2}{*}{\multicolumn{3}{|c|}{ L-E }} \\
\hline & & \\
\hline Agrostis alpina & NS & $\mathrm{C}^{* *}$ \\
\hline Helianthemum nuтmularium & NS & NS \\
\hline Lotus corniculatus & NS & $\mathrm{C}^{*}$ \\
\hline Polygonum viviparum & NS & $\mathrm{F}^{* * *}$ \\
\hline \multicolumn{3}{|l|}{ I-S } \\
\hline Alchemilla vulgaris & NS & NS \\
\hline Androsace vitaliana & NS & NS \\
\hline Geum montanum & NS & NS \\
\hline Veronica allionii & NS & NS \\
\hline \multicolumn{3}{|l|}{ I-E } \\
\hline Alchemilla hybrida & $\mathrm{P}^{*}$ & $\mathrm{~F}^{*} \S$ \\
\hline Leucanthemum adustum & $\mathrm{P} * *$ & $\mathrm{~F}^{* *}$ \\
\hline Lotus corniculatus & $\mathrm{P}^{*}$ & $\mathrm{~F}^{*}$ \\
\hline Phyteuma orbiculare & $\mathrm{P}^{*}$ & $\mathrm{~F}^{* *}$ \\
\hline \multicolumn{3}{|l|}{$\mathrm{H}-\mathrm{S}$} \\
\hline Geum montanum & NS & $\mathrm{F}^{* *}$ \\
\hline Poa alpina & NS & NS \\
\hline Ranunculus kuepferi & NS & NS \\
\hline Sibbaldia procumbens & NS & $\mathrm{F}^{*}$ \\
\hline \multicolumn{3}{|l|}{ H-E } \\
\hline Oxytropis helvetica & $\mathrm{P}^{*}$ & $\mathrm{~F} * * *$ \\
\hline Petrocallis pyrenaica & $\mathrm{N}^{* *}$ & NS \\
\hline Phyteuma pedemontana & $\mathrm{P} * *$ & $\mathrm{~F}^{* *}$ \\
\hline Polygonum viviparum & $\mathrm{P}^{* *}$ & $\mathrm{~F}^{* *}$ \\
\hline
\end{tabular}

Note: Abbreviations of sites are as in Table 1.

$* P<0.05$; ** $P<0.01$; *** $P<0.001$; NS $=$ not significant at $P<0.05$ level

$\dagger \mathrm{P}$ and $\mathrm{N}$ denote significant positive associations and significant negative associations, respectively. Spatial associations were calculated between each nondominant target species and the dominant graminoids (see Table 3 ).

$\$ \mathrm{C}$ and $\mathrm{F}$ denote significant competitive or facilitative responses to neighbor removal, respectively (see Fig. 2).

$\S$ Facilitative response only significant when pairs with a dead target added to the analysis.

sheltered sites to facilitation at high elevations and xeric, exposed sites. Our results for individual species and communities along elevational and topographical gradients support the basic conceptual model proposed by Bertness and Callaway (1994). Competitive effects of neighbors were much more prominent at sheltered sites and low elevations where productivity is higher, suggesting that abiotic stress is lower (see Grime 1977). Furthermore, changes in the effects of neighbors on particular species in experiments were associated with the location of the experimental site relative to the distributional optimum of the species. In experiments at sites higher in elevation than the distributional optimum of a species, the effect of neighbors was usually facilitative; in experiments at sites lower than the distributional optimum of a species the effect was usually competitive.

Our results described the response of species to manipulation of the entire matrix of all other surrounding plant species, and therefore did not examine the effects of specific neighbors. However, other studies have found similar shifts in competitive and facilitative effects on environmental gradients in experiments with pairs of species or a single target species vs. a functional group of species. On exposed ridges near timberline in the northern Rocky Mountains of Montana and Idaho, Abies lasiocarpa of all sizes are often highly aggregated around mature Pinus albicaulis, but aggregation does not occur at lower, protected sites (Callaway 1998b). Based on tree ring analyses, the diameter growth rates of mature Abies at timberline decreased by $24 \%$ when adjacent Pinus albicaulis died, but this growth response did not occur at lower elevations, suggesting that positive interactions among conifer species are important in the highly stressful conditions that occur at the altitudinal limits of tree growth. Other experimental studies in a variety of ecosystems have demonstrated shifts from competition in more benign, productive environments to facilitation in stressful environments in which productivity is low (Bertness and Shumway 1993, Greenlee and Callaway 1996, Kitzberger et al. 2000; but see Goldberg et al. [1999]).

Numerous other authors have reported strong spatial associations among species in alpine vegetation (Whitehead 1951, Griggs 1956, Bonde 1968, Blundon et al. 1983, Sohlberg and Bliss 1984, Alliende and Hoffman 1985, Kikvidze 1993, Anderson and Bliss 1998, Kikvidze and Nakhutsrishvili 1998, Pokarzhevskaya 1998, Nuñez et al. 1999). Most of these studies reported very high degrees of clumping of some species inside the cushions or tufts of others species. Furthermore, Kikvidze and Nakhutsrishvili (1998) found that species from low elevations were almost always associated with dominant cushion species at high-elevation "subnival" sites, but the high-elevation species were often found alone. To our knowledge, only a few studies have experimentally manipulated tundra vegetation prior to ours, and have only examined relationships between pairs of species (Sohlberg and Bliss 1987, McGraw and Chapin 1989, Carlsson and Callaghan 1991, Theodose and Bowman 1997, Olofsson et al. 1999). Our experimental results, in contrast with those of Olofsson et al. (1999), indicate that strong spatial associations are often indicative of positive interactions.

We do not know the mechanisms by which plants were facilitated by their neighbors. However, a number of environmental factors that occur at high or exposed sites are potentially ameliorated by neighbors. Surrounding vegetation may maintain warmer temperatures by insulating the substrate, decreasing local albedo, or by increasing the whole-community boundary layer. Continuous subsurface temperature measurements inside and outside graminoid tussocks at the intermediate-exposed site were substantially different during the growing season $(\mathrm{Ph}$. Choler, unpublished data). In soils not protected by graminoids, there were larger daily changes in temperature, with a higher fre- 
quency of freezing temperatures at night and higher maximum temperatures during the day (often $>40^{\circ} \mathrm{C}$ ). These trends may be amplified in the climate of the inner part of the Alps, where prolonged sunny periods, low relative humidity, and frequent extreme temperatures are common (Ozenda 1985).

Most facilitative effects involving drought involve distinct canopy and subcanopy species (Vetaas 1992, Callaway 1995), but, as in our study, other results indicate that interactions among species with similar morphologies can have important facilitative consequences for water relations. In northern Switzerland, taller grasses prevent dessication and frost heaving on limestone soils, increasing seedling survival by up to 10 times that of open patches (Ryser 1993). Hillier (1990) found stronger facilitative effects on drier grasslands than in wetter grasslands in Great Britain. Greenlee and Callaway (1996) found that a rare herbaceous mustard, Lesquerella carinata, was highly associated with bunchgrasses in a dry montane grassland in western Montana. In experiments that included bunchgrass removal and the construction of artificial shade, they found that shade facilitated Lesquerella in a dry year, but that bunchgrasses competed intensely with Lesquerella in a wet year.

Nitrogen is often limiting in cold environments (Bowman et al. 1993, Atkin 1996), and neighbors may either facilitate nitrogen availability or compete for nitrogen (Callaway et al. 1991, Tilman and Wedin 1991, Chapin et al. 1994), but little is known about the effect of neighbors on nitrogen acquistion in alpine systems. In the arctic, Fetcher (1985) found that shrub removal around Eriophorum vaginatum did not affect the nutrient regime of the tussock. In the alpine vegetation of the central Rocky Mountains, Trifolium species are estimated to contribute $0.5 \mathrm{mg} \mathrm{N} \cdot \mathrm{m}^{-2} \cdot \mathrm{yr}^{-1}$ to the nitrogen budget, a substantial portion of the $1.2 \mathrm{mg}$ $\mathrm{N} \cdot \mathrm{m}^{-2} \cdot \mathrm{yr}^{-1}$ estimate of total mineralized nitrogen (Bowman et al. 1996).

Alpine and arctic tundra are consistently exposed to strong winds, and the effect of wind increases with elevation and convex topography such as mounds and ridge tops. A likely explanation for the strong facilitative effects of neighbors at high elevations and exposed, convex topography is that plants embedded in the general vegetation matrix were protected from wind and wind-blown snow and ice. High and convex sites also may not retain a consistent protective snow cover due to wind, further exposing plants to the destructive forces of wind. Wind can damage plants by decreasing leaf and meristem temperatures, increasing vapor pressure differences between leaf and air, abrading tissue with particulates, or simply by battering leaves and branches among themselves and nearby objects (Wardle et al. 1998, Tranquillini 1980, Hadley and Smith 1983, 1986). Plants can benefit from being protected from wind by conspecifics or other species. Tree "islands" or "ribbon forests" often develop in windy sub- alpine areas, with seedling regeneration restricted to the leeward side of the islands or ribbons (Billings 1969, Minnich 1984). In the arctic, Carlsson and Callaghan (1991) showed that Carex bigelowii increased in leaf length and culm height when growing within clumps of Empetrum hermaphroditum or Racomitrium lanuginosum. They experimentally manipulated the effects of wind by erecting artificial shelters and found that they elicited similar positive responses from Car$e x$. If the primary facilitative mechanism operating at our more high and exposed sites was protection from wind, then the community-scale shift we observed from competition to facilitation may be much more pronounced in alpine communities than other types of communities where wind is not a stress factor. However, a vegetative matrix may provide many other kinds of positive feedback to individual plants, including maintaining a large-scale boundary layer, enhancing soil development and stability, or protection from some other kinds of disturbance (Wilson and Agnew 1992, Jones et al. 1994, 1997, Callaway 1995).

Small-scale disturbance may also play a role in the facilitative effect of dominant species. Heilbronn and Walton (1984) proposed that graminoids may initially be favored as colonizers of steep slopes because of their fibrous, highly branching roots, which stabilize sediments by limiting microsolifluction thereby creating stable islands for forbs.

Protection from desiccation, wind, cold temperatures, disturbance and enhanced nutrient availability are potential mechanisms for our observed increase in positive effects with elevation. However, the fact that the weaker axis (2) in the ordination was correlated with elevation and our strongest shifts in interaction strengths suggests that interspecific interactions are not the dominant structuring force in alpine communities. Numerous studies have emphasized the overwhelming importance of the abiotic environment in alpine communities (see Körner [1999] for a review), and our results do not indicate that adaptation to the abiotic environment is less important than thought. However, our results do suggest that shifts in interactions may alter fundamental abiotic niches by shifting the distributions of less stress-tolerant species upwards via facilitation and more stress-tolerant species upwards via competition.

A number of factors warrant consideration when interpreting our results. First, alpine tundra is generally dominated by graminoids, and a growing body of evidence has accumulated on the primary role played by these species on ecosystem processes (Grabherr 1989). Although we found positive effects of neighbors on graminoids in experiments, most of our target species were forbs that are thought by some to be competitively subordinate species in these communities (Grime 1998). Therefore, we may have underrepresented some of the dominant plants in the communities as target species, because they formed a matrix in which indi- 
viduals were hard to identify. If we overrepresented subordinate plants in our communities, we may have overestimated the overall importance of facilitation in these communities (see Fig. 2). However, we had the same experimental problem of choosing target species at the low sites, where competition was much more important.

Another potential limitation of our experiments is that all of the plants at our sites are clonal. We made efforts to choose small plants without obvious clonal connections at or near the surface, but the clonality of target species may have altered our results as sheltered ramets of clones may have supported exposed ramets (see Alpert and Mooney 1986, Pennings and Callaway 2000). The general effect of clonality on competition is controversial. Schmid and Bazzaz (1987) found that severing connections for Aster and Solidago species had minimal effect on intra- and interspecific competition. Similarly, de Kroon et al. (1992) reported that clonal integration did not have strong effects on intraspecific competition for Brachypodium pinnatum or Carex flacca. In field experiments using a large number of salt marsh species, Pennings and Callaway (2000) found that clonal integration appeared to be much more important for tolerating salt stress than competition from neighbors. In some experiments such as ours, severing connections around the target individuals has been be used to avoid the potential confounding effect of clonality (Gerdol et al. 2000). However, the fact that we found very similar results between the analysis of cespitose species and the analysis of all species suggests that clonal connections among species did not have important effects on our results.

We only removed aboveground biomass in our experiments and did not directly manipulate belowground interactions. In North American old fields, root competition has been shown to increase with decreasing soil fertility and community productivity; whereas shoot competition decreased (Wilson and Tilman 1991, 1995). Similar studies are rarer along elevation gradients, but Wilson (1993) showed that root competition increased with elevation from subalpine heath communities to alpine grass communities and that root: shoot ratios also increased along this gradient. Therefore it is possible that the stronger positive interactions we observed at high elevation might have been due to decreasing shoot competition overall, but increasing root competition in both the controls and the removals. We cannot exclude the possibility that our results were affected by such shifts in the importance of above- and belowground competition, but Körner (1999) has shown that comparisons of such ratios between lowland and alpine plants should be done within similar functional groups and that alpine plants are relatively conservative in biomass allocation when compared to similar growth forms at low elevations. Additionally, in field experiments Pennings and Callaway (1992) found that aboveground clipping also reduced competition for belowground resources.

We do not count out the importance of competitive interactions even in our most stressful sites. Experimental studies have demonstrated competition in exceptionally stressful environments (Ehleringer 1984), including alpine and arctic communities (McGraw 1985, McGraw and Chapin 1989, Theodose and Bowman 1997, Olofsson et al. 1999). Our results clearly show that the effects of neighbors depend on where an experiment is conducted relative to the distributional optimum of that species. If highly stress-tolerant species are experimental targets in a harsh environment, but not particularly harsh for that particular species, then competition may be expected.

Goodall (1966) proposed that the abundances of dominant, stress-tolerant species in a community were controlled primarily by abiotic gradients, whereas the abundance of less tolerant species may be controlled by the stress-tolerant species. At exposed sites, our results showed that rare species in communities were more likely to be facilitated than dominant species. This pattern suggests that dominant species may act to increase biological diversity in stressful environments.

Extreme fidelity of forbs for some dominant graminoids is a recurrent theme in the phytosociological literature (Theurillat et al. 1994), but the reliability of such correlational data has been questioned (Austin and Smith 1989, Callaway 1995). However, we found that highly clumped spatial distributions of species were often related to experimental evidence for facilitation. But we did not find highly species-specific spatial associations (see Callaway 1998a), which suggests that the same basic facilitative mechanism might operate for many different species in communities in stressful environments. Our experiments were not designed to detect species-specific effects of benefactors, as all neighbors were removed regardless of species.

To our knowledge, there have been no previous attempts to integrate experimental studies of plant-plant interactions with large-scale gradient analysis. The relative performance of species along environmental gradients has been estimated by statistical techniques derived from correspondence analysis and used to define species tolerance and niche breadth (Thioulouse and Chessel 1992). The data used to develop our gradients were floristic, therefore we did not measure species performance along direct environmental gradients. However, the primary goal of our gradient analysis was to place the experimental results in the context of the distributions of experimental species and relevés along the main ecological gradients. It is often assumed that performance of a species along a set of relevant environmental variables is sufficient to explain its distribution or fundamental niche (Osmond et al. 1987, Shugart 1998). Others have incorporated competitive and consumer interactions into definitions of the realized niche, and biotic interactions are now widely 
recognized as important driving forces shaping species distribution along gradients (Austin 1985). However, discrepancies between realized and fundamental niches have mainly been attributed to resource competition (Ellenberg 1953, McIntosh 1967, Whittaker 1967, Austin and Smith 1989).

Individualistic perspectives of plant communities hve led to a large amount of research on the importance of the abiotic environment and competition as factors that structure plant communities. The rationale for individualistic communities is based largely on gradient analyses, in which species are almost always distributed independently of one another in "continua" along environmental gradients (Gleason 1926, Curtis 1959, McIntosh 1967, Whittaker 1967, Austin 1985; but see Johnson and Mayeux [1992] for a more complete argument). In other words, the observation that the distributions of multiple species rarely overlap completely has been interpreted as a lack of interdependence among species. However, gradient analyses are correlative and do not demonstrate the processes that determine plant distributions and community organization. Our results have important implications for the interpretation of continua in plant communities. We showed that plant species may need their neighbors on some parts of continua, or gradients, but not on others. Our data suggest that facilitation may be an important process by which a species may broaden its distribution along an environmental gradient. We believe that if the presence of other species is crucial to the survival and performance of another species, then the community formed by these interactions does not fit the classical definition of an "individualistic" entity.

The development of general principles for understanding biotic interactions and their role in community and ecosystem processes requires the analysis of species performance under various conditions. For this, we suggest that the integrated approach of gradient analysis and manipulative experiments may have substantial heuristic value for discovering generality in community processes. Correlative, but quantitative, vegetation-environment studies provide a framework in which to address the importance of biotic interactions in the context of environmental gradients and spatial patterns. We believe our use of this integrated approach has provided evidence against a fully individualistic perspective on plant communities.

\section{ACKNOWLEDGMENTS}

The authors would like to acknowledge Erik Aschehoug, Cyril Delvalat, Christophe Mathieu, and Geneviève Girard who assisted in the field and the laboratory. The authors are also indebted to Christian Rolland for help with the statistical treatment of floristic data. Logistic support was provided in part by the Alpine Field station of Lautaret of the University of Grenoble. This work was funded by the "Laboratoire Ecosystèmes et Changements Environnementaux," University of Grenoble, The Civilian Research and Development Foundation GB1-117 (R. M. Callaway), and the National Geographic Society (R. M. Callaway). We thank S. D. Wilson and two anonymous reviewers for thoughtful and detailed comments on the manuscript.

\section{Literature Cited}

Aksenova, A. A., V. G. Onipchenko, and M. S. Blinnikov. 1998. Plant interactions in alpine tundra: 13 years of experimental removal of dominant species. Ecoscience 5: 258-270.

Alliende, M. C., and A. J. Hoffman. 1985. Plants intruding Laretia acaulis (Umbelliferae), a high Andean cushion plant. Vegetatio 80:151-156.

Alpert, P., and H. A. Mooney. 1986. Resource sharing among ramets in the clonal herb Fragaria chiloensis. Oecologia 70:227-233.

Anderson, D. G., and L. C. Bliss. 1998. Association of plant distribution patterns and microenvironments on patterned ground in a polar desert, Devon Island, N. W. T., Canada. Arctic and Alpine Research 30:97-107.

Atkin, O. K. 1996. Reassessing the nitrogen relations of Arctic plants: a mini-review. Plant, Cell and Environment 19: 695-704.

Austin, M. P. 1985. Continuum concept, ordination methods, and niche theory. Annual Review of Ecology and Systematics 16:39-61.

Austin, M. P., and T. M. Smith. 1989. A new model for the continuum concept. Vegetatio 83:35-47.

Bertness, M. D., and R. Callaway. 1994. Positive interaction in communities. Trends in Ecology and Evolution 9:191193.

Bertness, M. D., and S. D. Hacker. 1994. Physical stress and positive associations among marsh plants. American Naturalist 144:363-372.

Bertness, M. D., and S. W. Shumway. 1993. Competition and facilitation in marsh plants. American Naturalist 142:718724.

Billings, W. D. 1969. Vegetational pattern near alpine timberline as affected by fire-snowdrift interactions. Vegetatio 19:192-207.

Billings, W. D. 1974. Adaptations and origins of alpine plants. Arctic and Alpine Research 6:129-142.

Blundon, D., J. MacIssac, and R. T. Dale. 1983. Nucleation during primary succession in the Canadian Rockies. Canadian Journal of Botany 71:1093-1096.

Bonde, E. K. 1968. Survival of seedlings of an alpine clover (Trifolium nanum Torr.). Ecology 49:1193-1195.

Bounemoura, Z., K. Lambert, G. Cadel, Ph. Choler, O. Manneville, and R. Michalet. 1998. Influence des facteurs édaphoclimatiques sur la distribution des pelouses alpines dans le massif du Galibier (Alpes Françaises). Ecologie 29:53-58.

Bowman, W. D., J. C. Schardt, and S. K. Schmidt. 1996. Symbiotic N-fixation in alpine tundra: ecosystem input and variation in fixation rates among communities. Oecologia 108:455-450.

Bowman, W. D., T. A. Theodose, J. C. Schardt, and R. T. Conant. 1993. Constraints of nutrient availability on primary production in two alpine communities. Ecology $\mathbf{7 4}$ : 2085-2097.

Braun-Blanquet, J. 1926. Die alpinen planzengesellschaften. Pages 183-294 in J. Braun-Blanquet and H. Jenny, editors. Vegetations-entwicklung und bodenbildung in der alpinen stufe der zentralalpen. Denkschriften der Schweizerischen Naturforschenden Gesellshaft 63:I-VIII.

Braun-Blanquet, J. 1932. Plant sociology. McGraw-Hill, New York, New York, USA.

Brooker, R. W., and T. V. Callaghan. 1998. The balance between positive and negative plant interactions and its relationship to environmental gradients: a model. Oikos 81: 196-207.

Callaway, R. M. 1995. Positive interactions among plants. The Botanical Review 61:306-349. 
Callaway, R. M. 1997. Positive interactions in plant communities and the individualistic-continuum concept. Oecologia 112: 143-149.

Callaway, R. M. 1998a. Are positive interactions speciesspecific? Oikos 82:202-207.

Callaway, R. M. 1998b. Competition and facilitation on elevation gradients in subalpine forests of the northern Rocky Mountains, USA. Oikos 82:561-573.

Callaway, R. M., N. M. Nadkarni, and B. E. Mahall. 1991. Facilitation and interference of Quercus douglasii on understory productivity in central California. Ecology 72: 1484-1499.

Carlsson, B. A., and T. V. Callaghan. 1991. Positive plant interactions in tundra vegetation and the importance of shelter. Journal of Ecology 79:973-983.

Chapin, F. S., III, L. R. Walker, C. L. Fastie, and L. C. Sharman. 1994. Mechanisms of primary succession following deglaciation at Glacier Bay. Ecological Monographs 64: 149-175.

Curtis, J. T. 1959. The vegetation of Wisconsin. University of Wisconsin Press. Madison, Wisconsin, USA.

de Kroon, H., T. Hara, and R. Kwant. 1992. Size hierarchies of shoots and clones in clonal herb monocultures: do clonal and non-clonal plants compete differently? Oikos 63:410419.

del Moral, R. 1983. Competition as a control mechanism in subalpine meadows. American Journal of Botany 70:6981 .

Eddleman, L. E., and R. T. Ward. 1984. Phytoedaphic relationships in alpine tundra of north-central Colorado, USA. Arctic and Alpine Research 16:29-34.

Ehleringer, J. R. 1984. Intraspecific competitive effects on water relations, growth and reproduction in Encelia farinosa. Oecologia 63:153-158.

Ellenberg, H. 1953. Physiologisches und ökologishes Verhalten derselben Pflanzenarten. Berichtige des Deutschen Botanishe Gesellshaft 65:351-362.

Fetcher, N. 1985. Effects of removal of neighboring species on growth, nutrients, and microclimate of Eriophorum vaginatum. Arctic and Alpine Research 17:7-17.

Gensac, P. 1990. Plant and soil groups in the alpine grasslands of the Vanoise Massif, French Alps. Arctic and Alpine Research 22:195-201.

Gerdol, R., L. Brancaleoni, M. Menghini, and R. Marchesini. 2000. Response of dwarf shrubs to neighbour removal and nutrient addition and their influence on community structure in a subalpine heath. Journal of Ecology 88:256-266.

Gleason, H. A. 1926. The individualistic concept of the plant association. Bulletin of the Torrey Botanical Club 53:727.

Goldberg, D. E., T. Rajaniemi, J. Gurevitch, and A. StewartOaten. 1999. Empirical approaches to quantifying interaction intensity: competition and facilitation along productivity gradients. Ecology 80:1118-1131.

Goodall, D. W. 1966. The nature of the mixed community. Proceedings of the Ecological Society Australia 1:84-96.

Grabherr, G. 1989. On community structure in high alpine grasslands. Vegetatio 83:241-250.

Greenlee, J. T., and R. M. Callaway. 1996. Abiotic stress and the relative importance of interference and facilitation in montane bunchgrass communities in western Montana. American Naturalist 148:386-396.

Griggs, R. F. 1956. Competition and succession on a Rocky Mountain fellfield. Ecology 37:8-20.

Grime, J. P. 1977. Evidence for the existence of three primary strategies in plants and its relevance to ecological and evolutionary theory. American Naturalist 111:1169-1194.

Grime, J. P. 1998. Benefits of plant diversity to ecosystems: immediate, filter and founder effects. Journal of Ecology 86:902-910.
Hadley, J. L., and W. K. Smith. 1983. Influence of wind exposure on needle desiccation and mortality for timberline conifers in Wyoming, USA. Arctic and Alpine Research 15: $127-135$

Hadley, J. L., and W. K. Smith. 1986. Wind effects on needles of subalpine conifers: seasonal influence on mortality. Ecology 67:12-19.

Hedges, L. V., J. Gurevitch, and P. Curtis. 1999. The metaanalysis of response ratios in experimental ecology. Ecology 80:1150-1156.

Heilbronn, T. D., and W. H. Walton. 1984. Plant colonization of actively sorted stone stripes in the subantarctic. Arctic and Alpine Research 16:161-172.

Hillier, S. H. 1990. Gaps, seed banks, and plant species diversity in calcareous grasslands. In D. W. H. Walton and D. A. Wells, editors. Calcareous grasslands: ecology and management. Bluntisham Books, Huntingdon, UK.

Hunter, A. F., and L. W. Aarssen. 1988. Plants helping plants. Bioscience 38:34-40.

Isard, S. A. 1986. Factors influencing soil moisture and plant community distribution on Niwot Ridge, Front Range, Colorado, USA. Arctic and Alpine Research 18:295-304.

Johnson, H. B., and H. S. Mayeux. 1992. Viewpoint: a view on species additions and deletions and the balance of nature. Journal of Range Management 45:322-333.

Jones, C. G., J. H. Lawton, and M. Shachak. 1994. Organisms as ecosystem engineers. Oikos 69:373-386.

Jones, C. G., J. H. Lawton, and M. Shachak. 1997. Positive and negative effects of organisms as physical ecosystem engineers. Ecology 78:1946-1957.

Kikvidze, Z. 1993. Plant species associations in alpine-subnival vegetation patches in the Central Caucasus. Journal of Vegetation Science 4:297-302.

Kikvidze, Z., and G. Nakhutsrishvili. 1998. Facilitation in subnival vegetation patches. Journal of Vegetation Science 9:379-391.

Kirkpatrick, J. B., and K. L. Bridle. 1998. Environmental relationships of floristic variation in the alpine vegetation of southeast Australia. Australian Journal of Vegetation Science 9:577-588.

Kitzberger, T., D. F. Steinaker, and T. T. Veblen. 2000. Effects of climatic variability on facilitation of tree establishment in northern Patagonia. Ecology 81:1914-1924.

Komarkova, V., and P. J. Webber. 1978. An alpine vegetation map of Niwot Ridge, Colorado. Arctic and Alpine Research 10:1-29.

Körner, Ch. 1999. Alpine plant life. Springer, Berlin, Germany.

Markham, J. H., and C. P. Chanway. 1996. Measuring plant neighbour effects. Functional Ecology 10:548-549.

McGraw, J. B. 1985. Experimental ecology of Dryas octopetala ecotypes. III. Environmental factors and plant growth. Arctic and Alpine Research 17:85-98.

McGraw J. B., and F. S. Chapin III. 1989. Competitive ability and adaptation to fertile and infertile soils in two Eriophorum species. Ecology 70:736-749.

McIntosh, R. P. 1967. The continuum concept of vegetation. Botanical Review 33:130-187.

Minnich, R. A. 1984. Snow drifting and timberline dynamics on Mt. San Gorgonio, California, USA. Arctic and Alpine Research 16:395-412.

Moen, J. 1993. Positive versus negative interactions in a high alpine block field: germination of Oxyria digyna seeds in a Ranunculus digitalis community. Arctic and Alpine Research 25:201-206.

Nuñez, C. L., M. A. Aizen, and C. Ezcurra. 1999. Species association and nurse plant effects in patches of high Andean vegetation. Journal of Vegetation Science 10:357364.

Olofsson, J., J. Moen, and L. Oksanen. 1999. On the balance 
of positive and negative interactions in harsh environments. Oikos 86:539-543.

Osmond, C. B., M. P. Austin, J. A. Berry, W. D. Billings, J. S. Boyer, J. W. H. Dacey, P. S. Nobel, S. D. Smith, and W. E. Winner. 1987. Stress physiology and the distribution of plants. The survival of plants in any ecosystem depends on their physiological reactions to various stresses of the environment. Bioscience 73:38-48.

Ozenda, P. 1985. La végétation de la chaîne alpine dans l'espace montagnard européen. Masson, Paris, France.

Pennings, S. C., and R. M. Callaway. 1992. Salt marsh plant zonation: the relative importance of competition and physical factors. Ecology 73:681-690.

Pennings, S. C., and R. M. Callaway. 2000. The advantages of clonal integration under different ecological conditions: a community-wide test. Ecology 81:709-716.

Pokarzhevskaya, G. A. 1998. Influence of the dominant grass Festuca varia Haenke on the spatial pattern of alpine grasslands in the northwestern Caucasus, Russia. Arctic and Alpine Research 30:11-18.

Reynier, Ph. 1988. Etude phytoécologique, pédologique et statistique de stations sur schistes lustrés en haute Ubaye et régions avoisinantes, aux étages alpins et subalpins supérieur d'adret. Thesis. University of Grenoble, France.

Ryser, P. 1993. Influences of neighboring plants on seedling establishment in limestone grassland. Journal of Vegetation Science 4:195-202.

SAS Institute. 1985. SAS user's guide: statistics. SAS Institute, Cary, North Carolina, USA.

Schmid, B., and F. A. Bazzaz. 1987. Clonal integration and population structure in perennials: effects of severing rhizome connections. Ecology 68:2016-2022.

Shugart, H. H. 1998. Terrestrial ecosystems in changing environments. Cambridge University Press, Cambridge, UK.

Sohlberg, E. H., and L. C. Bliss. 1984. Microscale pattern of vascular plant distribution in two high arctic plant communities. Canadian Journal of Botany 62:14-20.

Sohlberg, E. H., and L. C. Bliss. 1987. Responses of Ranunculus sabinei and Papaver radicatum to removal of the moss layer in a high arctic meadow. Canadian Journal of Botany 65:1224-1228.

Sokal, R. R., and F. J. Rohlf. 1981. Biometry. Second edition. W. H. Freeman, New York, New York, USA.

ter Braak, C. J. F., and I. C. Prentice. 1988. A theory of gradient analysis. Advances in Ecological Research 18: 271-317.

Theodose, T. A., and W. D. Bowman. 1997. The influence of interspecific competition on the distribution of an alpine graminoid: evidence for the importance of plant competition in an extreme environment. Oikos 79:63-74.

Theurillat, J.-P., D. Aeschimann, P. Küpfer, and R. Spichiger. 1994. The higher vegetation units of the Alps. Colloques Phytosociologiques 23:189-239.

Thioulouse, J., and D. Chessel. 1992. A method for reciprocal scaling of species tolerance and sample diversity. Ecology 73:670-680.

Thioulouse, J., D. Chessel, S. Doledec, and J. M. Olivier. 1997. ADE-4: a multivariate analysis and graphical display software. Statistics and Computing 7:75-83.

Tilman, D., and D. A. Wedin. 1991. Dynamics of nitrogen competition between successional grasses. Ecology 72: $1038-1049$.

Tranquillini, W. 1980. Winter desiccation as the cause for alpine timberline. Pages 263-267 in U. Benecke and M. R. Davis, editors. Mountain environments and subalpine tree growth. Forest Research Institute, New Zealand Forest Service, Wellington, New Zealand.

Vetaas, O. R. 1992. Micro-site effects of trees and shrubs in dry savannas. Journal of Vegetation Science 3:334-337.

Walker, L. R., and F. S. Chapin III. 1987. Interactions among processes controlling successional changes. Oikos 50:131135.

Wardle, D. A., G. M. Barker, K. I. Bonner, and K. S. Nicholson. 1998. Can comparative approaches based on plant ecophysiological traits predict the nature of biotic interactions and individual plant species effects in ecosystems? Journal of Ecology 86:405-420.

Whitehead, F. H. 1951. Ecology of the Altiplano of Monte Maiella, Italy. Journal of Ecology 39:330-335.

Whittaker, R. H. 1967. Gradient analysis of vegetation. Biological Review 42:207-264.

Wilson, J. B., and A. D. Q. Agnew. 1992. Positive switches in plant communities. Advances in Ecological Research 23: 263-336.

Wilson, S. D. 1993. Competition and resource availability in heath and grassland in the Snowy Mountains of Australia. Journal of Ecology 81:445-451.

Wilson, S. D., and P. A. Keddy. 1986. Species competitive ability and position along a natural stress/disturbance gradient. Ecology 67:1236-1242.

Wilson, S. D., and D. Tilman. 1991. Components of plant competition along an experimental gradient of nitrogen availability. Ecology 72:1050-1065.

Wilson, S. D., and D. Tilman. 1995. Competitive responses of eight old-field plant species in four environments. Ecology 76:1169-1180. 